\title{
Congenital valvar aortic stenosis Natural history and assessment for operation
}

\author{
K F HOSSACK, J M NEUTZE, J B LOWE, B G BARRATT-BOYES \\ From the Cardiology and Cardiothoracic Surgical Units, Green Lane Hospital, Auckland, New Zealand
}

SUMMARY Two hundred and eighteen patients with congenital valvar aortic stenosis aged between 1 and 25 years at presentation were followed for one to 26 years (average 8.7 years). Assessment of severity of aortic stenosis was essentially based on clinical findings including symptoms, the character of the pulse, and the behaviour of the second heart sound, management being further influenced by the degree of left ventricular hypertrophy shown in the electrocardiogram. There was reasonable correlation between clinical and haemodynamic assessment and all patients with a gradient between left ventricle and aorta ( $\mathrm{LV}-\mathrm{Ao})$ greater than $50 \mathrm{mmHg}(6.7 \mathrm{kPa})$ were judged to have moderate or severe aortic stenosis on physical signs. Fifty-five per cent of those judged mild on presentation still had a mild lesion 18 years later; 42 per cent of those judged moderate on presentation still had a moderate lesion 15 years later. Forty-four patients had an operation and of the 30 patients who underwent aortic valvotomy, only 40 per cent still had a satisfactory result 13 years later. There were three preoperative and seven postoperative deaths but in only two patients was death directly related to severe aortic stenosis and both of these patients had been lost to follow-up.

It is concluded that indications for operation are aortic stenosis which is moderate or severe on physical findings, together with restrictive symptoms or ST and T wave changes on the electrocardiogram. Using these criteria, the risk of sudden death is minimal and irreversible myocardial damage unlikely. We do not recommend either routine cardiac catheterisation or routine operation at any arbitrary LV-Ao gradient.

The assessment and management of congenital aortic stenosis (AS) are still controversial. Traditionally, clinical signs, including the character of the pulse, behaviour of the second heart sound, and degree of left ventricular hypertrophy have been the main criteria of severity. Several authors ${ }^{1-3}$ have suggested that analysis of the carotid upstroke is a helpful method of assessing severity, Gray ${ }^{4}$ and Braunwald et $a l .{ }^{5}$ reported a reasonable correlation between severity and the behaviour of the second heart sound, and Marquis and Logan ${ }^{6}$ found that electrocardiographic evidence of left ventricular hypertrophy was the most reliable single sign of severe AS. On the other hand, there have been many reports suggesting that physical findings $\mathrm{s}^{7-12}$ and the electrocardiogram ${ }^{5} 71314$ are unreliable. In most studies each factor has been analysed separately, and even when summation of

\footnotetext{
^ Present address: Division of Cardiology, Department of Medicine, University of Washington, Seattle 98195, Washington, USA. Received for publication 1 August 1979
}

factors has been attempted certain items have been omitted. For example, Eddleman et al..$^{15}$ excluded evaluation of the second heart sound and Ellison et al..$^{16}$ omitted analysis of the pulse contour.

The reported incidence of sudden death in children with congenital AS varies between 1 and 19 per cent. ${ }^{6} 817-21$ Doubts about the reliability of physical signs, demonstration of increasing severity of obstruction in many patients, and concern about sudden death have led a number of authors to recommend repeated left heart catheterisation to determine whether mild lesions are becoming more severe. ${ }^{9-11}$ Morrow et al. ${ }^{22}$ stated that "the correlation presented between symptoms, physical signs and the severity of the obstruction demonstrates that the interpretations of clinical findings are not sufficiently reliable to permit them to be utilised in the important decision as to operation".

In published reports there is wide variation in the recommended indications for aortic valvotomy, with a tendency in recent years to recommend 
earlier operation. Despite the fact that valvotomy is only a palliative procedure, this operation has been recommended for patients who are asymptomatic but have peak systolic pressure gradients between left ventricle and aorta (LV-Ao) of $50 \mathrm{mmHg}(6.7 \mathrm{kPa})$ or more. ${ }^{22-26}$

We have not accepted the view that clinical assessment of the severity of the lesion is unreliable or that a peak systolic LV-Ao pressure difference of $50 \mathrm{mmHg}(6.7 \mathrm{kPa})$ in an asymptomatic patient is an indication for operation. Admitting the variation in clinical presentation, we believe that sudden death is exceedingly rare in the absence of specific clinical findings, and contend that symptomatic and clinical assessment can provide the criteria for operation in most patients. In view of this disagreement with many previous publications we have reviewed our experience with this condition.

\section{Patients}

Patients with valvar AS referred to Green Lane Hospital in the years 1948 to 1976 inclusive have been reviewed. Because the management of AS in the young infant poses special problems, we have restricted this study to those presenting beyond 1 year of age, and we have also arbitrarily excluded those presenting beyond 25 years. A confident clinical diagnosis of congenital valvar AS was made in each patient and serial follow-up examinations were carried out. The minimal criteria for inclusion of patients with mild AS were the presence of a basal ejection murmur radiating to the carotid vessels almost always accompanied by a systolic ejection click, and prominence of the ascending aorta in the chest radiograph. Two hundred and sixty-four patients had mild congenital AS at the time of referral, but 111 of these were excluded from the study group because they had been seen on only one occasion. The study group comprises 218 patients; on referral 153 were considered to have a mild lesion, 54 a moderate lesion, and 11 a severe lesion. There were 160 male and 58 female patients. Four patients had associated coarctation of the aorta, two had coarctation of the aorta and a persistent ductus arteriosus, and one had coarctation of the aorta with pulmonary arterial branch stenoses. Two patients had Turner's syndrome. Thirteen per cent of the 218 patients had trivial or mild aortic regurgitation (AR) on presentation but patients with significant AR (i.e. a leak of sufficient magnitude to have a definite effect on the pulse) were excluded from the study. During the period under review approximately 2000 further patients were seen because of an ejection murmur, and a congenital anomaly of the aortic valve is probably the commonest lesion in this group, but only those with unequivocal signs of aortic stenosis have been included in the study.

In the follow-up study, patients last recorded as having moderate or severe stenosis have been reviewed within the past two years. Details of patients last recorded as having mild stenosis have been obtained from the last clinic review, usually within the past five years. Duration of follow-up ranged from one to 26 years (average $8 \cdot 7$ years).

Symptoms and physical, electrocardiographic, and radiological findings were recorded at referral and at last review for all patients, and immediately before operation in patients undergoing surgery. These details were also recorded at the time of cardiac catheterisation when this took place between referral and operation or last review. The criteria used for assessing the severity of AS on the basis of physical signs were as follows:

Mild aortic stenosis: Pulse volume and contour were normal on palpation and the second heart sound was normal.

Moderate aortic stenosis: There was a minor abnormality in one or more of the above signs. Pulse volume appeared abnormal more often than contour. Narrow inspiratory splitting of the second heart sound was allowed, but not a single second sound or reversed splitting.

Severe aortic stenosis: Any one of these three clinical features (pulse volume, pulse contour, or splitting of the second heart sound) was conspicuously abnormal.

Table 1 shows the arbitrary grading of the electrocardiogram used for the assessment of left ventricular hypertrophy. Though the voltage criteria for mild left ventricular hypertrophy are weak, the voltage criteria for moderate left ventricular hypertrophy are strict to avoid false positives.

The LV-Ao systolic pressure difference was measured at cardiac catheterisation in 65 patients.

Table 1 Electrocardiographic criteria of left ventricular hypertrophy

\begin{tabular}{|c|c|c|}
\hline & Voltages & $\begin{array}{l}T \text { wave in left chest } \\
\text { leads }\end{array}$ \\
\hline & $\begin{array}{l}\text { S V1 }+ \text { R V5 } \\
\text { or } \\
\text { S V2 + R V6 }\end{array}$ & \\
\hline $\begin{array}{l}\text { Mild } \\
\text { Moderate either } \\
\text { or }\end{array}$ & $\begin{array}{l}35 \text { to } 60 \mathrm{~mm} \\
>60 \mathrm{~mm} \\
35 \text { to } 60 \mathrm{~mm}\end{array}$ & $\begin{array}{l}\text { Normal } \\
\text { Normal } \\
\text { Reduced amplitude/ } \\
\text { flat/biphasic } \\
\text { Inverted }\end{array}$ \\
\hline
\end{tabular}


Seven patients had two preoperative studies and seven patients had both a pre- and a postoperative study, making a total of 79 catheterisations. Cardiac output was measured by Fick or dye dilution method on 63 occasions and aortic valve area index was calculated on 32 occasions.

Six patients developed significant AR during follow-up. In four this was a result of bacterial endocarditis and in two it was apparently spontaneous.

Forty-four patients have had operations at our hospital. Four had transventricular valvotomy (before 1959), 30 had transaortic valvotomy, one had an exploration of the aortic valve without aortic valvotomy, and nine had homograft aortic valve replacement. Three additional patients were operated on elsewhere and have not been included in the detailed surgical analysis but have been included in the actuarial curves for the progression of the severity of aortic lesions.

Differences between groups were assessed by Student's unpaired t test.

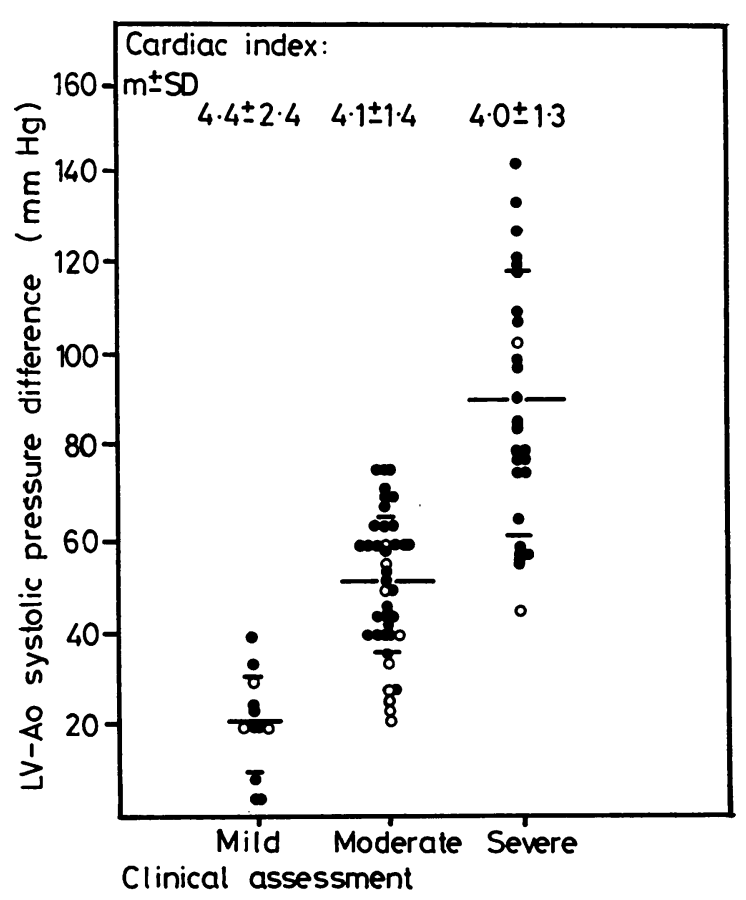

Fig. 1 Relation between clinical assessment and peak LV-Ao systolic pressure difference. Open circles, patients with some aortic regurgitation; bars show mean values \pm 1 standard deviation.

Significance of differences between groups: mild vs moderate, $p<0.001$; moderate vs severe, $p<0.001$; mild vs severe, $p<0.001$ ( $1 \mathrm{mmHg} \approx 0.133 \mathrm{kPa})$.

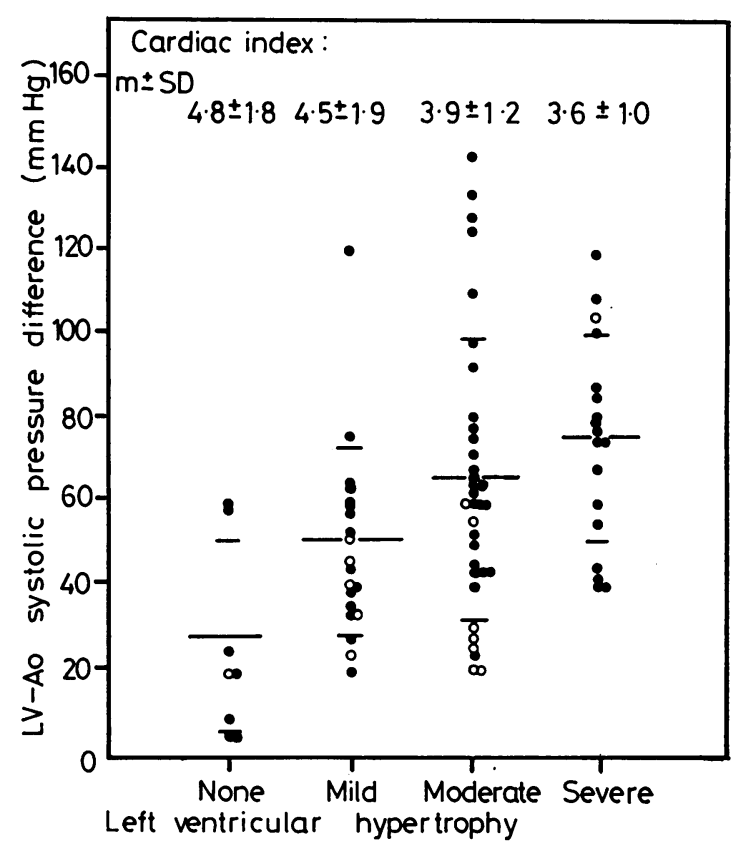

Fig. 2 Relation between electrocardiographic assessment of left ventricular hypertrophy ( $L V H$ ) and peak $L V$-Ao pressure difference. Significance of differences between groups: normal vs severe LVH, $p<0.001$; normal vs moderate $L V H, p<0.005$; normal vs mild $L V H, p<0.05$; mild $L V H$ vs severe $L V H, p<0.005$; mild $L V H$ vs moderate $L V H, p<0.05$; moderate $L V H$ vs severe LVH, NS. Seven patients had moderate LVH on voltage criteria alone.

\section{Results}

COMPARISONS BETWEEN CLINICAL ASSESSMENT AND HAEMODYNAMIC DATA Clinical assessment was based primarily on subjective assessment of the second heart sound and of the pulse volume and contour. In patients whose pulses were judged to be of normal volume, the measurements of pulse pressure by sphygmomanometry were $40 \pm 13 \mathrm{mmHg}(5 \cdot 3 \pm 1 \cdot 7 \mathrm{kPa}$, mean \pm 1 SD), in those with a mildly abnormal pulse $32 \pm 12 \mathrm{mmHg}(4.3 \pm 1.6 \mathrm{kPa})$, and in those with a conspicuously abnormal pulse $25 \pm 7 \mathrm{mmHg}(3 \cdot 3 \pm$ $0.9 \mathrm{kPa}$ ). Though there was a considerable overlap, the differences between each group were highly significant $(p<0.001)$ and the maximum pulse pressure in the severe group was $40 \mathrm{mmHg}$.

Thirty-one of the 218 patients presented with or developed symptoms. These were exertional dyspnoea in 19, dyspnoea and angina in six, dyspnoea and syncope in four, angina with syncope in one, and syncope alone in one. Twenty-six of 
these patients were assessed on physical signs as severe and five, all with dyspnoea alone, as moderate. The electrocardiogram showed severe left ventricular hypertrophy in 19, moderate in eight, and mild in three, while in one there was complete heart block. Twenty-nine of these 31 patients have had, or await, operation.

Fig. 1 shows the relation between the assessment of physical signs and the LV-Ao pressure difference in the 79 studies. All patients with a pressure difference greater than $40 \mathrm{mmHg}(5.3 \mathrm{kPa})$ were judged moderate or severe on physical signs. Of the 23 patients with gradients greater than $75 \mathrm{mmHg}$ $(10.0 \mathrm{kPa}), 87$ per cent were judged as severe and the remainder moderate. Of the 39 patients with gradients between 35 and $75 \mathrm{mmHg}(4 \cdot 7$ and 10.0 $\mathrm{kPa}), 82$ per cent were assessed as moderate and all but one of the remainder were assessed as severe. Of the 17 patients with gradients of less than $35 \mathrm{mmHg}(4 \cdot 7 \mathrm{kPa}), 65$ per cent were assessed as mild; five of the remaining six patients had mild associated aortic regurgitation, and these and one other were assessed as moderate.

Fig. 2 shows the relation between the electro-

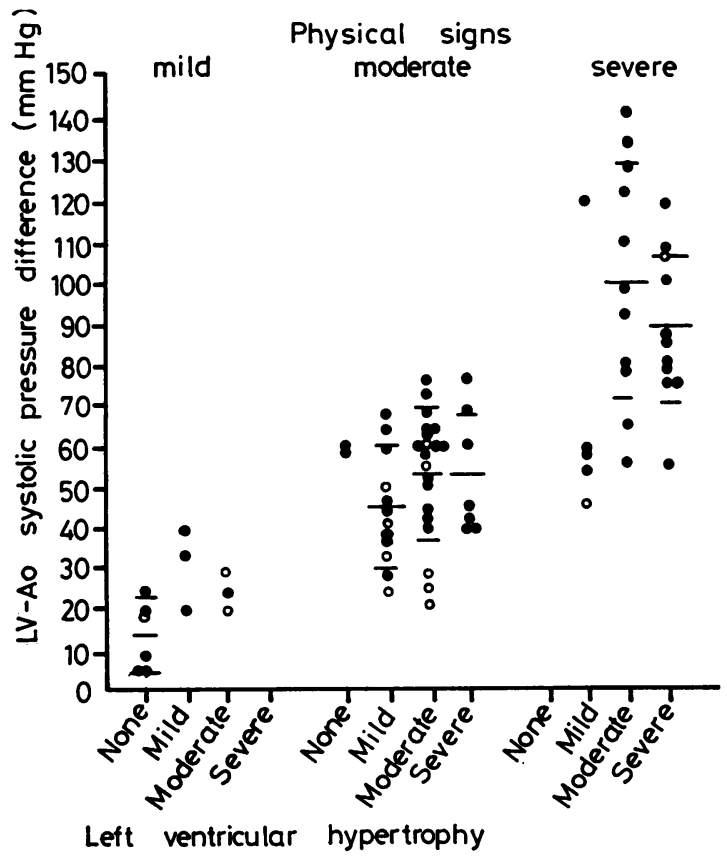

Fig. 3 Relation between physical signs, electrocardiographic assessment, and $L V$-Ao pressure difference. Conventions as in Fig. 1. Patients assessed as moderate on physical signs show similar pressure gradients whether the electrocardiogram shows moderate or severe $L V H$ : the same is true of those judged severe on physical signs, but gradients are higher than those in the moderate group. cardiographic findings and the LV-Ao pressure difference. The distinction between groups is less clear than that shown with physical signs. Examination of the interrelations between physical signs, electrocardiograms, and LV-Ao pressure differences (Fig. 3) shows that consideration of the electrocardiogram did not increase the accuracy of the clinical assessment. In the group judged moderate on physical signs, the range of LV-Ao pressure differences was similar whether the electrocardiogram showed moderate or severe left ventricular hypertrophy, the mean LV-Ao pressure difference in each case being just over $50 \mathrm{mmHg}(6.7 \mathrm{kPa})$. In the group judged severe on physical signs, the range of LV-Ao pressure differences was again similar whether the electrocardiogram showed moderate or severe left ventricular hypertrophy; the mean was about $85 \mathrm{mmHg}(11.3 \mathrm{kPa})$ in those with severe left ventricular hypertrophy and was actually higher in those with moderate left ventricular hypertrophy though the difference was not statistically significant.

The cardiothoracic ratio bore no relation to the LV-Ao pressure difference. The cardiothoracic ratios were also compared with the assessment of physical signs. In patients over 21 years of age the mean cardiothoracic ratio was slightly higher in those judged severe than in those judged moderate $(50.5 \%$ vs $46.6 \%, \mathrm{p}<0.05)$ but no other significant relations were observed.

The correlation between the LV-Ao pressure difference and the calculated aortic valve area index was relatively weak (Fig. 4, $r=0.576$ by simple regression). The aortic valve area index did not correlate as well as the LV-Ao pressure difference with the physical assessment of AS or the electrocardiographic assessment of left ventricular hypertrophy. Other catheterisation data are summarised in Table 2.

Table 2 Cardiac catheterisation data

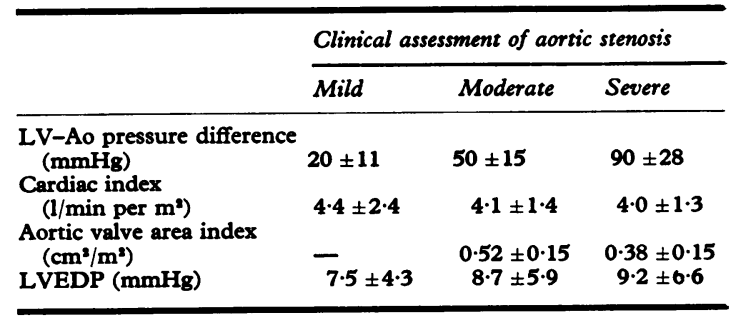

Values given are mean \pm 1 standard deviation.

Significance of differences:

LV-Ao pressure difference: mild vs moderate $\quad \mathrm{p}<0.001$ moderate vs severe $\quad \mathrm{p}<0.001$

Aortic valve area index: moderate vs severe $p<0.05$ Other differences were not significant. $\quad 1 \mathrm{mmHg}=0.133 \mathrm{kPa}$. 


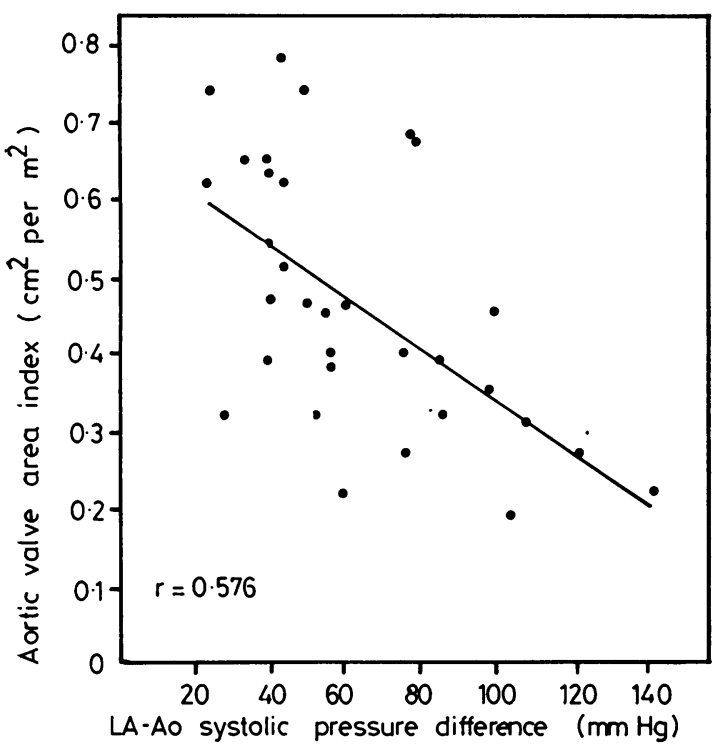

Fig. 4 Relation between peak $L V$-Ao pressure difference and aortic valve area index. There is a wide scatter of values.

FOLLOW-UP DATA

Fig. 5 shows the cumulative actuarial curves ${ }^{27}$ for the 153 patients who presented with mild AS. One patient died in this group (case 1, Table 3 ). Fifty-five per cent of the patients remained with mild AS after 18 years but the remainder developed a more severe lesion, judged sufficiently important to warrant operation in 23 per cent.

Fig. 6 shows the cumulative actuarial curves for the 54 patients presenting with moderate AS. Two patients died in this group (cases 2 and 3, Table 3). Forty-two per cent of the group remained with moderate AS after 15 years but the remainder developed a more severe lesion, and 42 per cent underwent operation.

Eleven patients with a mean age of 12.6 years presented with severe AS and had an operation within 12 months of presentation.

The mean age of presentation in the 44 patients who had an operation was 10 years ( 1 to 25 years) and the mean age at the time of operation was 14.2 years ( 1 to 35 years). There were 30 male and 14 female patients. Before operation 25 patients had symptoms, including four with heart failure. One patient had severe AR after bacterial endocarditis and the clinical data in the remaining 43 patients are shown in Table 4. In six patients physical signs and electrocardiogram indicated only moderate AS: three of these had symptoms and had gradients of 28,54 , and $76 \mathrm{mmHg}(3 \cdot 7,7 \cdot 2$, and $10 \cdot 1 \mathrm{kPa})$, but
Table 3 Deaths

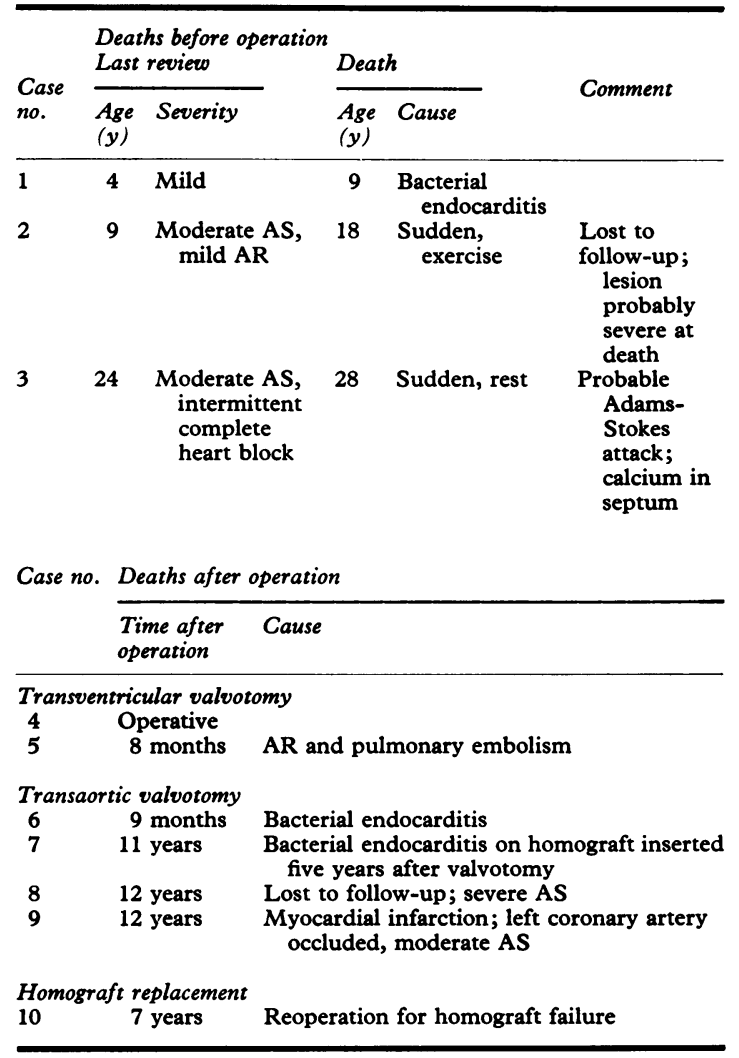

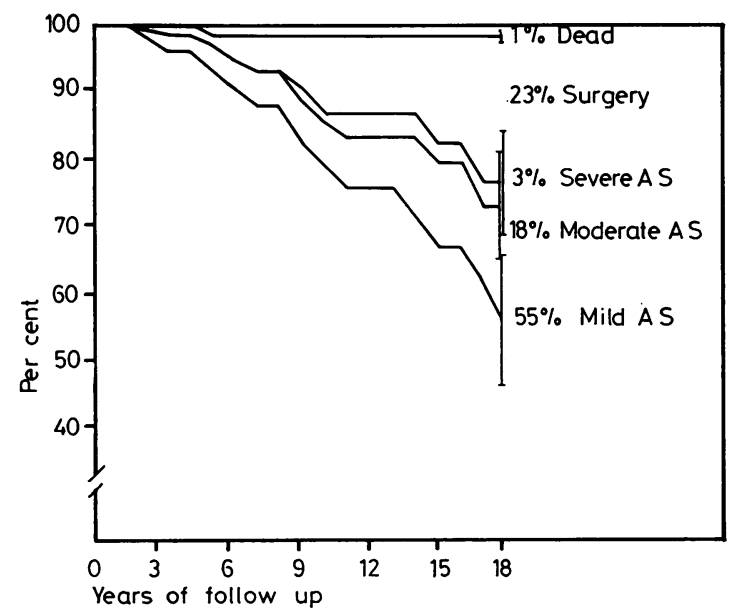

Fig. 5 Cumulative actuarial curves of 153 patients presenting with mild aortic stenosis. The actuarial curves are plotted to the point where the smallest subgroup has 10 members at risk. Bars show \pm 1 standard error at this point. Mean age at presentation, 6.5 years (range 1 to 25 years); mean follow-up, 8.8 years (range 1 to 26 years). 
the clinical status of the first patient was probably misjudged; in the three without symptoms the gradient was not measured in two and in the other was $98 \mathrm{mmHg}(13.0 \mathrm{kPa})$. All six had a valvotomy though two would not require operation by our current criteria; one has mild AS 17 years later and the other moderate AS/AR 17 years later.

Four patients had a transventricular aortic valvotomy. There was one operative death and one late death (cases 4 and 5, Table 3), one patient had severe AR 22 years after operation, and one patient has mild AS 10 years after operation.

The mean age at presentation in the 30 patients who had a transaortic valvotomy was 8.8 years ( 1 to 25 years) and the mean age at the time of operation was $12 \cdot 1$ years ( 2 to 30 years). Fig. 7 shows the cumulative actuarial curve for this group, the mean follow-up period being 13 years. There were no operative deaths but there have been four late deaths (cases 6 to 9, Table 3). Ten patients required later aortic valve replacement. The reason for reoperation was recurrent AS in seven patients and severe $A R$ in three. The mean time between aortic valvotomy and aortic valve replacement was 9.1 years (range of four to 14 years). There were no hospital deaths after reoperation but there was one late death (case 7, Table 3). Of the 17 other surviving patients, eight have a significant residual lesion: four have moderate AS and four moderate

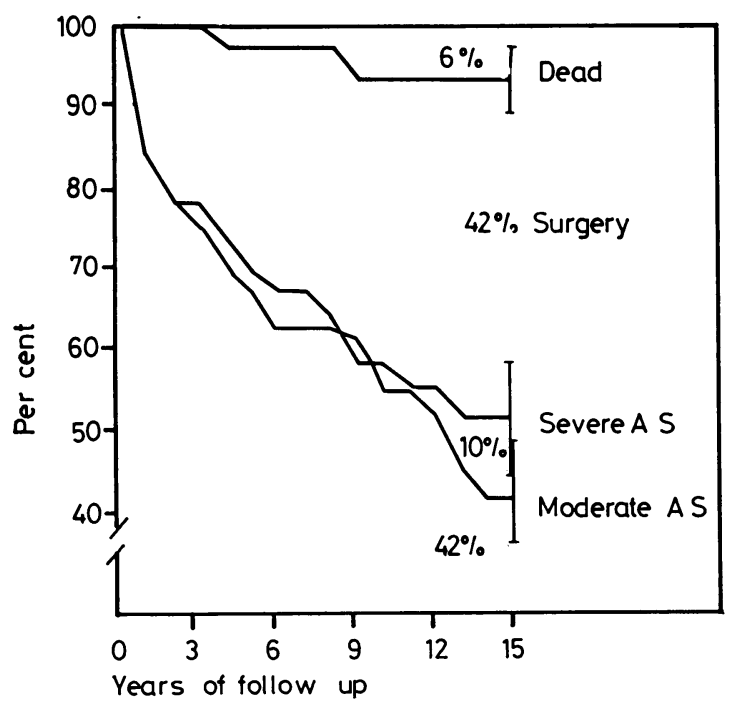

Fig. 6 Cumulative actuarial curves of 54 patients presenting with moderate aortic stenosis. Conventions as in Fig. 5. Mean age at presentation, 11.8 years (range 1 to 25 years). Mean follow-up, 8.5 years (range 1 to 24 years).

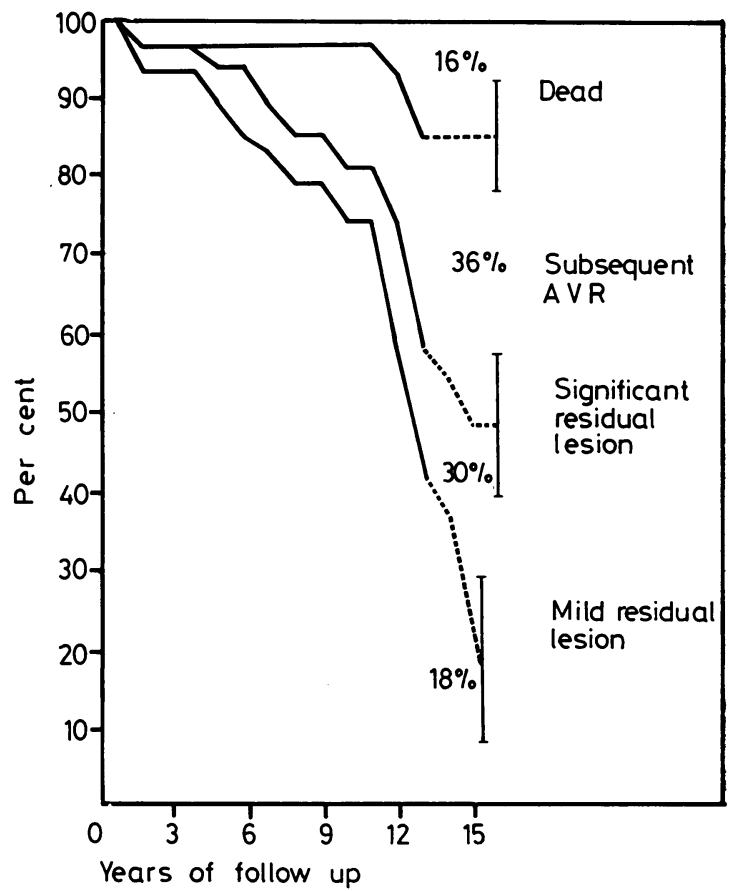

Fig. 7 Cumulative actuarial curves of 30 patients undergoing transaortic valvotomy. Conventions as in Fig. 5 In the period from 13 to 15 years (dotted curves) eight patients were at risk in the smallest subgroup.

AS/AR. The development of significant AR after valvotomy was unrelated to the number of valve cusps, occurring in three of 10 with a tricuspid valve and in five of 19 with a bicuspid valve, but not in the one patient with a unicuspid valve.

One patient had an exploration of the aortic valve with a view to aortic valvotomy which was judged impractical on direct inspection. Preoperatively the pressure gradient was only $40 \mathrm{mmHg}$ $(5.3 \mathrm{kPa})$ but the electrocardiogram showed severe

Table 4 Preoperative findings in 43 surgical patients ${ }^{\star}$

\begin{tabular}{|c|c|}
\hline \multicolumn{2}{|l|}{25 Patients with symptoms } \\
\hline $\begin{array}{l}\text { Physical signs } \\
\text { Electrocardiographic evidence of } \\
\text { left ventricular hypertrophy } \\
\text { LV-Ao pressure difference } \\
\text { (15 patients) }\end{array}$ & $\begin{array}{l}\text { Severe } 22 \text {, moderate } 3 \\
\text { Severe } 16 \text {, moderate } 7 \text {, mild } 2 \\
\text { Range } 28 \text { to } 134 \mathrm{mmHg} \\
\text { mean } 71 \mathrm{mmHg} \\
\text { ( } 3 \text { below } 50 \mathrm{mmHg} \text { ) }\end{array}$ \\
\hline \multicolumn{2}{|l|}{18 Patients without symptoms } \\
\hline $\begin{array}{l}\text { Physical signs } \\
\text { Electrocardiographic evidence of } \\
\text { left ventricular hypertrophy } \\
\text { LV-Ao pressure difference } \\
\text { (12 patients) }\end{array}$ & $\begin{array}{l}\text { Severe } 11 \text {, moderate } 7 \\
\text { Severe } 6 \text {, moderate } 9 \text {, mild } 3 \\
\text { Range } 50 \text { to } 142 \mathrm{mmHg} \\
\text { mean } 82 \mathrm{mmHg}\end{array}$ \\
\hline
\end{tabular}

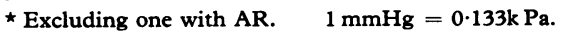


left ventricular hypertrophy. Fifteen years later the patient has minor symptoms, the gradient is $65 \mathrm{mmHg}$, and valve replacement is planned.

Nine patients had homograft aortic valve replacement as the primary operation. The mean age at presentation was 12.5 years ( 6 to 23 years) and the mean age at operation was 23.6 years (14 to 35 years). Preoperatively, six patients had significant AR associated with AS, and two others had a calcified aortic valve. There were no early deaths. One patient died after a second operation for homograft failure (case 10, Table 3), one required reoperation because of endocarditis on the homograft valve, and one patient has been lost to followup. The other six patients are alive and well.

Table 5 lists the significant postoperative complications which occurred in the patients having aortic valvotomy or homograft aortic valve replacement.

In 24 patients who had satisfactory operations, follow-up electrocardiograms were available at a time when the residual aortic lesion was judged trivial or mild. A comparison of pre- and postoperative electrocardiograms in this group is shown in Table 6. Most patients showed improvement in the electrocardiogram and in two-thirds this was sufficient to move them at least one grade in the arbitrary classification.

\section{BACTERIAL ENDOCARDITIS}

Three non-surgical patients had bacterial endocarditis, with one death. Two patients who subsequently had an operation had endocarditis before operation. From the time the patients were referred to the clinic the incidence of bacterial endocarditis without, or before surgery, was $2 \cdot 7$ episodes per 1000 patient years.

Table 5 Postoperative complications in patients undergoing aortic valvotomy or primary homograft aortic valve replacement

\begin{tabular}{lll}
\hline Complications & $\begin{array}{l}\text { Aortic } \\
\text { valvotomy } \\
(30)\end{array}$ & $\begin{array}{l}\text { Homograft aortic } \\
\text { valve replacement } \\
(9)\end{array}$ \\
\hline $\begin{array}{l}\text { Wound infection } \\
\begin{array}{l}\text { False aneurysm of femoral } \\
\text { artery at site of cannulation }\end{array}\end{array}$ & 3 & 0 \\
$\begin{array}{l}\text { Myocardial damage (new } \\
\begin{array}{l}\text { Q waves) } \\
\text { Haemorrhage }\end{array}\end{array}$ & 0 & 0 \\
$\begin{array}{l}\text { Postcardiotomy syndrome } \\
\text { Cerebral embolism with } \\
\text { recovery }\end{array}$ & 1 & 2 \\
$\begin{array}{l}\text { Ventricular tachycardia } \\
\text { Reoperation for malpositioned } \\
\text { aortic homograft }\end{array}$ & 1 & 1 \\
$\begin{array}{l}\text { Total number of patients with } \\
\text { complications }\end{array}$ & 0 & 0 \\
\hline
\end{tabular}

Table 6 Comparison of degree of left ventricular hypertrophy in pre- and postoperative electrocardiograms in 24 patients with trivial or mild residual lesion ${ }^{\star}$

\begin{tabular}{lrllll}
\hline $\begin{array}{l}\text { Left ventricular } \\
\text { hypertrophy in initial } \\
\text { electrocardiogram }\end{array}$ & \multicolumn{4}{l}{$\begin{array}{l}\text { Left ventricular hypertrophy in follow-up } \\
\text { electrocardiogram }\end{array}$} \\
\cline { 2 - 6 } & & None & Mild & Moderate & Severe \\
\hline Severe & 13 & 5 & 1 & 4 & 3 \\
Moderate & 7 & 3 & 2 & 2 & \\
Mild & 4 & 1 & 3 & & \\
\hline
\end{tabular}

* Duration of follow-up 20 to 173 months (mean 96).

Figures given are the numbers of patients in each category.

Four patients had bacterial endocarditis postoperatively, one after valvotomy $(2 \cdot 8$ episodes per 1000 patient years) and three after homograft aortic valve replacement (34 episodes per 1000 patient years), one of the latter having also had an attack before operation. This, presumably by chance, is higher than the average incidence for endocarditis on homograft valves in this hospital, which is 57 episodes in 5274 patient years, or 10.8 per 1000 patient years. The overall postoperative incidence in the present study was 8.9 episodes per 1000 patient years. Numbers are too small for statistical assessment.

\section{Discussion}

This study was arbitrarily restricted to patients presenting between the ages of 1 and 25 years to provide a relatively uniform group. There are special problems associated with aortic stenosis in neonates, and patients who present after the age of 25 usually do so with calcific aortic stenosis. The group of 2000 patients with a systolic murmur may include several hundred patients with trivial AS whose prognosis is almost certainly better than that of the study group. This study, therefore, describes the progress of 218 patients with typical signs of valvar AS; it is possible that a few patients with membranous subaortic stenosis have been included with those who have had neither cardiac catheterisation nor operation but this should not materially affect the conclusions.

\section{RELIABILITY OF PHYSICAL SIGNS}

Dyspnoea, angina, or syncope usually indicate a severe lesion, ${ }^{828}$ and in our series 85 per cent of the 31 patients with symptoms were judged at that time to have a severe lesion. The development of symptoms is, however, influenced by factors other than the severity of obstruction, and only 26 of 56 patients with a severe lesion had symptoms.

The intensity of the systolic murmur, the presence of a thrill, an apical fourth heart sound, and a thrusting left ventricular impulse are typical of AS 
but do not reliably predict the severity of the obstruction. Several authors have investigated the relation between the LV-Ao pressure difference and the pulse pressure, the character of the pulse, and the second heart sound. Both Peckham et al., ${ }^{19}$ and Glew et al. ${ }^{8}$ comment on the usefulness of a small pulse pressure as an indication of moderate or severe AS. We have used a subjective impression of the pulse volume and contour at a large artery, usually the brachial artery. Correlation with measured pulse pressure is not exact but the reduced pulse pressure probably contributes to the impression of an altered pulse contour. Beyond the infant age group detection of an altered pulse contour in a large artery is remarkably reproducible, and Eddleman et al..$^{15}$ showed that a slow carotid upstroke was the best of the factors they analysed in predicting an LV-Ao pressure difference of $50 \mathrm{mmHg}(6.7 \mathrm{kPa})$ or more.

Braunwald et al. ${ }^{5}$ found that the mean LV-Ao pressure difference in patients with a single second sound on phonocardiography was $100 \mathrm{mmHg}$ $(13.3 \mathrm{kPa})$ and in patients with a narrowly split second sound was $49 \mathrm{mmHg}(6.5 \mathrm{kPa})$. We have not used phonocardiography on a regular basis but have found that assessment of the second heart sound is generally reproducible between experienced observers. Difficulties resulting from conduction anomalies or heavily calcified valves rarely arise in patients of the age group in this study.

Most of the authors who criticise the accuracy of physical signs studied a mixed group of patients; for example, the group of Braunwald et al. ${ }^{5}$ included 20 per cent with other lesions $(12 \%$ with shunts). Concentration on a single sign further limits the sensitivity of clinical assessment. In the absence of any complicating factor we have taken a minor or pronounced abnormality of any one sign as an indication of moderate or severe stenosis, respectively. When comparisons were made with LV-Ao pressure differences there was, as expected, some overlap between the mild and moderate and between the moderate and severe groups, but not between the mild and severe groups (Fig. 1). Excluding those with severe AR, patients with lesions judged mild had an LV-Ao pressure difference less than $40 \mathrm{mmHg}(5.3 \mathrm{kPa})$ and those with lesions judged severe had a gradient greater than $55 \mathrm{mmHg}(7 \cdot 3 \mathrm{kPa})$. Some of the overlap seen is to be expected when gradients are compared without taking account of variations in cardiac output, and the use of calculated aortic valve area has great theoretical appeal. The number of patients in the present series with valve area calculations is relatively small (Fig. 4), but, like Miettinen and Rees, ${ }^{29}$ we were disappointed to find no practical advantage in the use of valve areas; the correlations with clinical and electrocardiographic assessments were less good with valve area than with LV-Ao pressure difference.

Many authors have commented that important AS can occur with a normal electrocardiogram, and our study confirms this, bearing in mind that many electrocardiograms were graded as showing mild left ventricular hypertrophy on voltage criteria which overlap the normal range in this age group. On the other hand, Hohn et al. ${ }^{14}$ reported an abnormal electrocardiogram in 79 per cent of patients with an LV-Ao pressure difference greater than $50 \mathrm{mmHg}(6.7 \mathrm{kPa})$ and in 90 per cent of patients with a pressure difference greater than $77 \mathrm{mmHg}$ $(10.3 \mathrm{kPa})$. In our series, 37 of 47 patients with a pressure difference greater than $50 \mathrm{mmHg}(6.7 \mathrm{kPa})$ had moderate or severe left ventricular hypertrophy as did 16 of 18 with a pressure difference greater than $75 \mathrm{mmHg}(10.0 \mathrm{kPa})$. We deliberately kept the voltage criteria for moderate left ventricular hypertrophy strict: $\mathbf{7 5}$ per cent of patients classified as having moderate left ventricular hypertrophy fell into this category because of $S T$ and $T$ wave abnormalities, and the voltage evidence in the remainder was very impressive. Surprisingly, inclusion of the electrocardiogram in the clinical assessment did not improve the correlation with LV-Ao pressure differences (Fig. 3). Nevertheless, the development of ST and T wave changes in the electrocardiogram is important, probably representing relative impairment of subendocardial coronary blood flow. In patients with important AS such electrocardiographic changes can be produced by exercise, making the exercise electrocardiogram a more sensitive test. ${ }^{30-32}$ It is significant that the indirect assessment of the adequacy of coronary perfusion (DPTI/SPTI) was found to be related to the electrocardiographic change, ${ }^{33}$ and a slightly modified version of this index correlated well with symptoms. ${ }^{34}$ The presence of $S T$ and $T$ wave changes in the electrocardiogram can, therefore, usually be taken as an indication of severe obstruction, though there are exceptions as shown by our patient who remained well 15 years after exploration of his aortic valve. Not surprisingly, plain chest $x$ rays made no significant contribution to the assessment of severity.

We conclude that assessment of symptoms, physical findings, and the electrocardiogram provides information which is sufficiently accurate to determine management in most cases. We have little experience with other non-invasive methods using systolic time intervals, analysis of the carotid upstroke, vectorcardiography, and apex cardiography, ${ }^{1-3} 13$ but question whether they add 
materially to the precision of assessment. Newer techniques in radiology, ${ }^{35} \mathrm{M}$-mode echocardiography, ${ }^{36}{ }^{37}$ or cross-sectional echocardiography, ${ }^{38}$ may well do so, but whether or not they will enter general clinical use remains to be seen.

\section{RISK OF SUDDEN DEATH}

The main reason for requiring accurate assessment is the risk of sudden death, a subject emphasised repeatedly in the published reports. The incidence of sudden death in AS has varied in different reports according to selection but is probably in the region of 1 per cent. ${ }^{20}{ }^{21}$ In the collaborative study of Lambert et $a .^{39}$ all patients who died suddenly had severe left ventricular hypertrophy on the electrocardiogram. After reviewing published data, Doyle et al..$^{28}$ concluded that sudden death in the absence of severe electrocardiographic abnormalities and/or symptoms is very uncommon. Of the 10 patients in our series who died, death was attributable directly to aortic stenosis in only two (cases 2 and 8 , Table 3), both of whom had been lost to follow-up for many years.

Table 7 shows those published cases of sudden death without ST and T wave changes: it is clear that sudden death in patients with no symptoms and normal physical findings has not been documented. The risk of sudden death, directly attributable to AS, is virtually limited to those patients with a severe lesion. We have already given our reasons for believing that physical findings provide a reliable indication of an important obstruction even when the electrocardiogram is normal. For these reasons we regard careful clinical assessment as adequate protection against the catastrophe of sudden death and do not accept the need for routine cardiac catheterisation recommended by others. ${ }^{9-11}$

\section{INDICATIONS FOR OPERATION}

In deciding the indications for operation, it must be borne in mind that aortic valvotomy is no panacea. In Table 8 we have summarised a number of published results. As far as possible, we have extracted data to include only patients who had valvar AS and who were over the age of 1 year. Overall, the early operative mortality is low but late mortality is greater and, to some extent, dependent upon the length of follow-up. Furthermore, bacterial endocarditis, the redevelopment of significant aortic valve lesions, and reoperation occur with increasing frequency. About 75 per cent of our patients had a mild residual lesion at 10 years but from this time there was a dramatic increase in the number of patients who either required reoperation or had an important residual lesion (Fig. 7). Sudden death still occurred despite valvotomy though some cases were avoidable

Table 7 Summary of patients with normal ST segments and $T$ waves who died suddenly $\dagger$

\begin{tabular}{|c|c|c|c|c|c|c|c|c|c|}
\hline Author & $\begin{array}{l}\text { Case } \\
\text { no. }\end{array}$ & $\begin{array}{l}\text { Age } \\
(y)\end{array}$ & Symptoms & Pulse volume & $\begin{array}{l}\text { Pulse } \\
\text { character }\end{array}$ & $\begin{array}{l}\text { Second } \\
\text { sound }\end{array}$ & Electrocardiogram & Catheterisation & $\begin{array}{l}\text { Activity } \\
\text { at death }\end{array}$ \\
\hline \multirow[t]{2}{*}{$\begin{array}{l}\text { Braverman } \\
\text { and } \\
\text { Gibson }^{17}\end{array}$} & 1 & 4 & $\begin{array}{l}\text { Syncope, } \\
\text { dyspnoea }\end{array}$ & NS & NS & NS & $\begin{array}{l}\text { Normal (10 mth } \\
\text { before death) }\end{array}$ & - & Sleeping \\
\hline & 2 & 9 & Fatigue & BP $84 / 60$ & NS & NS & $\begin{array}{l}\text { WPW (2 } \frac{3}{4} \text { y } \\
\text { before death) }\end{array}$ & - & Standing \\
\hline $\begin{array}{l}\text { Reynolds } \\
\text { et al. }{ }^{40}\end{array}$ & 3 & 4 & $\begin{array}{l}\text { Syncope, } \\
\text { heart failure }\end{array}$ & BP $80 / 60$ & NS & NS & $\begin{array}{l}\text { Mild LVH* }(2 \text { wk } \\
\text { before death })\end{array}$ & 一 & $\begin{array}{l}\text { Resting in } \\
\text { bed }\end{array}$ \\
\hline $\begin{array}{l}\text { Landtman } \\
\text { et } a l .^{41}\end{array}$ & 4 & 10 & $\begin{array}{l}\text { Dyspnoea } \\
\quad(\text { for } 5 \mathrm{y})\end{array}$ & NS & NS & NS & $\begin{array}{l}\text { LVH (time before } \\
\text { death NS) }\end{array}$ & - & NS \\
\hline Campbell $^{20}$ & 5 & 12 & $\begin{array}{l}\text { Angina, } \\
\text { syncope, } \\
\text { dyspnoea }\end{array}$ & NS & NS & NS & $\begin{array}{l}\text { Mild LVH* (4 } \\
\text { mth before } \\
\text { death) }\end{array}$ & $\begin{array}{l}36 \text { mmHg LV- } \\
\text { Ao pressure } \\
\text { difference } 6 \text { y } \\
\text { before death }\end{array}$ & Walking \\
\hline Glew et al. ${ }^{8}$ & 5 & $23 / 12$ & Syncope & Normal & NS & NS & $\begin{array}{l}\text { Mild } \mathrm{LVH}^{\star}(2 \mathrm{wk} \\
\text { before death })\end{array}$ & - & NS \\
\hline \multirow[t]{2}{*}{ Reid et al. ${ }^{42}$} & 7 & 8 & Nil & NS & NS & NS & $\begin{array}{l}\text { Mild LVH (time } \\
\text { before death NS) }\end{array}$ & - & Football \\
\hline & 8 & 15 & Nil & NS & NS & NS & $\begin{array}{l}\text { Mild LVH (time } \\
\text { before death NS) }\end{array}$ & 一 & Swimming \\
\hline $\begin{array}{l}\text { Wagner } \\
\text { et al. }{ }^{12}\end{array}$ & 9 & 16 & NS & NS & NS & NS & $\begin{array}{l}\text { NS (presumably } \\
\text { no } T \text { wave } \\
\text { changes at time } \\
\text { of catheterisation) }\end{array}$ & $\begin{array}{l}68 \mathrm{mmHg} \mathrm{LV}- \\
\text { Ao pressure } \\
\text { difference } 17 \\
\text { mth before } \\
\text { death }\end{array}$ & Basketball \\
\hline
\end{tabular}

NS, not stated.

$\star$ We have used our criteria for left ventricular hypertrophy where records are available.

+ Three cases listed by Doyle et al.$^{28}$ have not been included because one had subvalvar AS, one died of a ruptured subclavian aneurysm, and one had left bundle-branch block with signs of severe aortic stenosis. 
emphasising the need for meticulous follow-up of patients both before and after operation. There was no evidence that the incidence of bacterial endocarditis was reduced by operation. On the contrary, the findings are compatible with the suggestion of Gersony and Hayes ${ }^{49}$ that the incidence may be increased.

Although this is frequently recommended, ${ }^{22-26}$ we can find no justification either in our data or in other published reports for advising valvotomy simply because the LV-Ao gradient is greater than $50 \mathrm{mmHg}(6.7 \mathrm{kPa})$. It is at approximately this level that symptoms develop in some patients, the lesion begins to appear important on physical signs, and $S T$ depression or T inversion may appear, but, on the other hand, many patients show none of these features and tolerate obstruction of this severity for long periods. Wagner et al. ${ }^{12}$ presented data which suggested that results with surgical treatment were better than results with medical treatment in patients with a gradient of 50 to $79 \mathrm{mmHg}(6.7$ to $10.5 \mathrm{kPa})$ : one surgical patient and four medical patients died. The significance of this is, however, doubtful, as three surgical patients and one medical patient whose gradients fell just outside this range also died. It is disappointing that the use of valve area does not provide a clearer criterion for recommending operation. This is no doubt partly the result of errors in measurement, but we believe that it is also partly because of a variation in effective valve area dependent on the strength of contraction of the left ventricle at the time of measurement. Fortunately, very low cardiac outputs are unusual at the time of study in this age group so that a gross. underestimate of severity is not common. By contrast, an overactive circulation is not uncommon and the LV-Ao gradient on its own quite frequently gives an exaggerated impression of severity. Other methods of assessment of the severity of the lesion based on oxygen requirements ${ }^{34}$ have not so far provided a clearer cut-off point.

We do not recommend operation for patients who are free from symptoms and who do not show at least moderate changes in the pulse, second heart sound, or electrocardiogram, even though there are many such patients with an LV-Ao pressure difference greater than $50 \mathrm{mmHg}$. Dyspnoea,

Table 8 Results of aortic valvotomy in published reports

\begin{tabular}{|c|c|c|c|c|c|c|c|c|c|}
\hline Author & $\begin{array}{l}\text { No. of } \\
\text { patients }\end{array}$ & $\begin{array}{l}\text { Mean length } \\
\text { of follow-up } \\
\text { (range) }\end{array}$ & $\begin{array}{l}\text { Early } \\
\text { mortality }\end{array}$ & $\begin{array}{l}\text { Late } \\
\text { mortality }\end{array}$ & $\begin{array}{l}\text { Reoperation } \\
\text { rate }\end{array}$ & $\begin{array}{l}\text { Significant } \\
A R\end{array}$ & $\begin{array}{l}\text { Significant } \\
A S\end{array}$ & $\begin{array}{l}\text { Endo- } \\
\text { carditis }\end{array}$ & $\begin{array}{l}\text { Good } \\
\text { result }\end{array}$ \\
\hline Spencer et al..$^{43}$ & 8 & $\begin{array}{l}\text { NS } \\
\text { (1-6 mth) }\end{array}$ & 0 & 0 & NS & $25 \%$ & $12.5 \%$ * & 0 & NS \\
\hline Lees et al..$^{44}$ & 26 & $\begin{array}{l}17 \text { mth } \\
(9 \mathrm{mth} \text { to } \\
\left.3 \frac{1}{2} \mathrm{y}\right)\end{array}$ & $4 \%$ & 0 & NS & $4 \%$ & $\begin{array}{c}29 \% \text { ( } 2 \text { of } 7 \\
\text { studied) }\end{array}$ & 0 & NS \\
\hline Morrow et al..$^{22}$ & 27 & 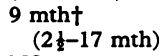 & $10 \%$ & 0 & NS & $14 \%$ & $7 \%$ & NS & NS \\
\hline Cooley et al. ${ }^{24}$ & 55 & NS & $1.8 \%$ & NS & NS & NS & NS & NS & NS \\
\hline $\begin{array}{l}\text { Thomson and } \\
\text { Fisher }^{45}\end{array}$ & 23 & $\begin{array}{l}3 \cdot 4 \mathrm{y} \\
(1-6 \mathrm{y})\end{array}$ & 0 & $4 \%$ & $4 \%$ & $22 \%$ & $4 \%$ & NS & $74 \%$ \\
\hline Fisher et al. ${ }^{40}$ & 26 & $\begin{array}{l}18 \mathrm{mth} t \\
(6 \mathrm{mth} \text { to } \\
5 \mathrm{y})\end{array}$ & 0 & $4 \%$ & NS & $8 \%$ & $20 \%$ & NS & $68 \%$ \\
\hline $\begin{array}{c}\text { Shackleton } \\
\text { et al. }{ }^{47}\end{array}$ & 25 & $\begin{array}{l}7 \cdot 5 \mathrm{y} \\
(3-10 \mathrm{y})\end{array}$ & $4 \%$ & $8 \%$ & $8 \%$ & $20 \%$ & NS & NS & NS \\
\hline $\begin{array}{l}\text { Bernhard } \\
\text { et al. }{ }^{.5}\end{array}$ & 116 & $\begin{array}{l}\text { NS } \\
(1-15 y)\end{array}$ & $2.5 \%$ & $5 \%$ & $10 \%$ & $43 \%$ & $14 \%$ & $1 \%$ & NS \\
\hline Conkle et al..$^{26}$ & 38 & $10 \underset{(5-14 y)}{y}$ & 0 & $2.5 \%$ & $8 \%$ & $10 \%$ & $16 \%$ & $10 \%$ & $69 \%$ \\
\hline $\begin{array}{l}\text { Jack and } \\
\text { Kelly }^{48}\end{array}$ & $\begin{array}{l}42 \text { ( }>2 \text { y of } \\
\text { age, } 5 \text { lost to } \\
\text { follow-up) }\end{array}$ & $\begin{array}{l}10 \cdot 6 \mathrm{y} \\
(6-16.3 \mathrm{y})\end{array}$ & 0 & $8 \%$ & $\begin{array}{l}11 \% \text { (recom- } \\
\text { mended in } \\
27 \% \text { ) }\end{array}$ & $25 \%$ & $\begin{array}{l}40 \% \text { (6 of } 15 \\
\text { studied pre- } \\
\text { and postop) }\end{array}$ & $5 \cdot 5 \%$ & $56 \%$ \\
\hline Wagner et al. ${ }^{12}$ & $\begin{array}{c}162 \text { ( }>2 \text { y of } \\
\text { age) }\end{array}$ & $\begin{array}{l}6.5 y+ \\
(3-9 y)\end{array}$ & $1.2 \%$ & $2 \cdot 4 \%$ & NS & $4 \cdot 7 \%$ & $34 \cdot 6 \%$ & NS & $\begin{array}{l}35 \%(45 \\
\text { of } 127)\end{array}$ \\
\hline Present data & 30 & $13 y$ & 0 & $13 \%$ & $33 \%$ & $27 \%$ & $40 \% \ddagger$ & $7 \%$ & $30 \%$ \\
\hline
\end{tabular}

^ LV-Ao pressure difference estimated at operation.

+ Time of catheterisation.

$¥$ Assessed clinically.

NS, not stated.

Data include only patients with valvar aortic stenosis who were older than 1 year of age. Non-cardiac deaths have been excluded from

late mortality. Significant aortic regurgitation is defined as pulse pressure greater than $50 \mathrm{mmHg}$; some of the difference between series is a result of different methods of data presentation. Significant aortic stenosis is defined as peak $\mathbf{L V}$-Ao pressure difference of $50 \mathrm{mmHg}$ or greater. A good result is an asymptomatic patient who has mild aortic stenosis or mild aortic regurgitation. 
confidently attributed to the cardiac lesion, indicates moderate or severe obstruction but, where other findings are compatible with a moderate lesion only, dyspnoea occurs only with strenuous exertion, and the patient can avoid extremes of exertion without seriously interfering with his lifestyle, we believe it reasonable to continue careful observation. On the other hand, syncope or angina indicates a severe lesion, almost always an indication for operation. The reason why one patient develops symptoms and another with a seemingly identical lesion does not is presumably related to the habitual level of physical exercise, the personality of the individual and his level of autonomic responsiveness, and probably to the physical characteristics of the pulmonary vascular bed. Some patients with signs of a severe lesion have no symptoms and, provided that extremes of exercise are avoided, continued observation is permissible until such time as the electrocardiogram begins to show significant ST depression or $\mathrm{T}$ inversion. Even then long survival is possible, as shown by the presentation of patients late in life with calcific AS, some of whom have probably maintained this situation for decades. Furthermore, ST and $\mathrm{T}$ wave changes, at least those of moderate degree, will usually regress after a satisfactory operation (Table 6). Nevertheless, the low mortality and morbidity of aortic valvotomy, the risk of sudden death, and the likelihood of progressive myocardial impairment with long-term subendocardial ischaemia are sufficient reasons for recommending valvotomy in the presence of these electrocardiographic changes. We have not accepted that routine preoperative cardiac catheterisation is mandatory but in practice have investigated many patients to add to the precision of assessment, particularly when there is any discrepancy between symptoms, physical signs, and the electrocardiogram. In older patients, coronary arteriography is also desirable. Though we have not accepted any LV-Ao pressure difference as an absolute indication for operation, in practice a gradient of 75 or $80 \mathrm{mmHg}(10.0$ or $10.6 \mathrm{kPa})$ is usually associated with symptoms if the patient leads an active life and with clinical signs of severe obstruction including, sooner or later, ST or T wave changes on the electrocardiogram.

The criteria for recommending operation amount to the presence of physical signs of moderate or severe obstruction, combined either with significant symptoms or with pathological ST and T wave changes on the electrocardiogram. With the few exceptions described earlier, these criteria have been used during the period of this study. With these criteria, the risk of sudden death is minimal and irreversible myocardial changes are unlikely to occur. In a patient who is probably faced with several operations in his lifetime, we do not believe surgical intervention warranted until these criteria are fulfilled. If it could be shown that early valvotomy slowed the progression of thickening and calcification of the valve, more liberal criteria for operation would be appropriate, but we know of no such evidence and doubt if the proportion of patients benefiting from this would be sufficient to justify early operation as a routine. Though cineangiographic assessment of the valve has improved in recent years, it is still not possible, in our hands, to predict those patients in whom an excellent result will be obtained. However, the risk of producing significant AR has diminished over the years. Earlier reports suggested that AR developed most frequently when an inappropriate attempt was made to render the valve tricuspid, ${ }^{22} 45$ but our series shows no relation between anatomy and the development of AR. Though this risk is now small we do not at present feel that attempted valvotomy is warranted unless the lesion is severe enough to justify valve replacement should the anatomy be unfavourable.

\section{References}

'Epstein EJ, Coulshed N. Assessment of aortic stenosis from the external carotid pulse wave. Br Heart $\mathcal{F} 1964$; 26: 84-96.

${ }^{2}$ Lyle DP, Bancroft WH Jr, Tucker M, Eddleman EE Jr. Slopes of the carotid pulse wave in normal subjects, aortic valvular disease and hypertrophic subaortic stenosis. Circulation 1971 ; 43: 374-8.

${ }^{3}$ Bonner AJ Jr, Sacks HN, Tavel ME. Assessing the severity of aortic stenosis by phonocardiography and external carotid pulse recordings. Circulation 1973; 48: 247-52.

${ }^{4}$ Gray IR. Paradoxical splitting of the second heart sound. Br Heart F 1956; 18: 21-8.

${ }^{5}$ Braunwald E, Goldblatt A, Aygen MM, Rockoff SD, Morrow AG. Congenital aortic stenosis. I. Clinical and haemodynamic findings in 100 patients. Circulation 1963; 27: 426-50.

'Marquis RM, Logan R. Congenital aortic stenosis and its surgical treatment. Br Heart $\mathcal{F}$ 1955; 17: 373-90.

'Jones RC, Walker WJ, Jahnke EJ, Winn DF Jr. Congenital aortic stenosis-correlation of clinical severity with hemodynamic and surgical findings in 43 cases. Ann Intern Med 1963; 58: 486-93.

${ }^{8}$ Glew RH, Varghese PJ, Krovetz LJ, Dorst JP, Rowe RD. Sudden death in congenital aortic stenosis. A review of eight cases with an evaluation of premonitory clinical features. Am Heart f 1969; 78: 615-25.

${ }^{\circ}$ Friedman WF, Modlinger J, Morgan JR. Serial hemodynamic observations in asymptomatic children with valvar aortic stenosis. Circulation 1971; 43: 91-7. ${ }^{10}$ Cohen LS, Friedman WF, Braunwald E. Natural history of mild congenital aortic stenosis elucidated by 
serial hemodynamic studies. Am $\mathcal{F}$ Cardiol 1972; 30: $1-5$.

${ }^{11}$ El-Said G, Galioto FM Jr, Mullins CE, McNamara DC. Natural hemodynamic history of congenital aortic stenosis in childhood. Am $\mathcal{F}$ Cardiol 1972; 30: 6-12.

${ }^{12}$ Wagner HR, Ellison RC, Keane JF, Humphries JO, Nadas AS. Clinical course in aortic stenosis. Circulation 1977; 55 and 56, suppl I: 47-56.

${ }^{13}$ Hugenholtz PG, Lees MM, Nadas AS. The scalar electrocardiogram, vectorcardiogram and exercise electrocardiogram in the assessment of congenital aortic stenosis. Circulation 1962; 26: 79-91.

${ }^{14} \mathrm{Hohn}$ AR, Van Praagh S, Moore AAD, Vlad P, Lambert EC. Aortic stenosis. Circulation 1965; 31 and 32, suppl III : 4-12.

${ }^{15}$ Eddleman EE Jr, Frommeyer WB Jr, Lyle DP, Bancroft WH Jr, Turner ME Jr. Critical analysis of clinical factors in estimating severity of aortic valve disease. Am $\mathcal{F}$ Cardiol 1973; 31: 687-95.

${ }^{16}$ Ellison RC, Wagner HR, Weidman WH, Miettinen OS. Congenital valvular aortic stenosis. Clinical detection of small pressure gradient. Am f Cardiol 1976; 37: 757-61.

${ }^{17}$ Braverman IB, Gibson S. The outlook for children with congenital aortic stenosis. Am Heart f 1957; 53: 487-93.

${ }^{18}$ Ongley PA, Nadas AS, Paul MY, Rudolph AM, Starkey GWB. Aortic stenosis in infants and children. Pediatrics 1958; 21 : 207-21.

${ }^{19}$ Peckham GB, Keith JD, Evans JR. Congenital aortic stenosis. Some observations on the natural history and clinical assessment. Can Med Assoc F 1964; 91 : 639-43.

${ }^{20} \mathrm{Campbell} M$. The natural history of congenital aortic stenosis. Br Heart $\mathcal{F}$ 1968; 30: 514-26.

${ }^{21}$ Thornback P, Fowler RS. Sudden unexpected death in children with congenital heart disease. Can Med Assoc f 1975; 113: 745-8.

${ }^{22}$ Morrow AG, Goldblatt A, Braunwald E. Congenital aortic stenosis II. Surgical treatment and the results of operation. Circulation 1963; 27: 450-62.

${ }^{23}$ Ellis FH Jr, Ongley PA, Kirklin JW. Results of surgical treatment for congenital aortic stenosis. Circulation 1962; 25: 29-38.

${ }^{24}$ Cooley DA, Beall AC Jr, Hallman GL, Bricker DL. Obstructive lesions of the left ventricular outflow tract. Surgical treatment. Circulation 1965; 31: 612-21.

${ }^{25}$ Bernhard WF, Keane JF, Fellows KE, Litwin SB, Gross RE. Progress and problems in the surgical management of congenital aortic stenosis. $\mathcal{F}$ Thorac Cardiovasc Surg 1973; 66: 404-19.

${ }^{26}$ Conkle DM, Jones M, Morrow AG. Treatment of congenital aortic stenosis. An evaluation of the late results of aortic valvotomy. Arch Surg 1973; 107: 649-51.

${ }^{27}$ Anderson RP, Bonchek LI, Grunkemeier GE, Lambert LE, Starr A. The analysis and presentation of surgical results by actuarial methods. $\mathcal{f}$ Surg Res 1974; 16: 224-30.

${ }^{28}$ Doyle EF, Arumugham P, Lara E, Rutkowski MR, Kiely B. Sudden death in young patients with congenital aortic stenosis. Pediatrics 1974; 53: 481-9.

${ }^{29}$ Miettinen OS, Rees JK. Report from the Joint Study on the Natural History of Congenital Heart Defects. II. Methodology. Circulation 1977; 55 and 56, suppl I: 5-12.

${ }^{30}$ Halloran $\mathrm{KH}$. The telemetered exercise electrocardiogram in congenital aortic stenosis. Pediatrics $1971 ; 47$ : 31-9.

${ }^{31}$ Chandramouli B, Ehmke DA, Lauer RM. Exerciseinduced electrocardiographic changes in children with congenital aortic stenosis. $\mathcal{F}$ Pediatr 1975; 87: 725-30.

${ }^{32}$ Hossack KF, Neilson GH. Exercise testing in congenital aortic stenosis. Aust NZ F Med 1979; 9: 169-73.

${ }^{33}$ Lewis AB, Heymann MA, Stanger P, Hoffman JIE, Rudolph AM. Evaluation of subendocardial ischemia in valvar aortic stenosis in children. Circulation 1974; 49: 978-84.

${ }^{34}$ Krovetz LJ, Kurlinski JP. Subendocardial blood flow in children with congenital aortic stenosis. Circulation 1976; 54: 961-5.

${ }^{35}$ Trenouth RS, Phelps NC, Neill WA. Determinants of left ventricular hypertrophy and oxygen supply in chronic aortic valve disease. Circulation 1976; 53: 644-50.

${ }^{38}$ Glanz S, Hellenbrand WE, Berman MA, Talner NS. Echocardiographic assessment of the severity of aortic stenosis in children and adolescents. Am f Cardiol 1976; 38: 620-25.

${ }^{37}$ Blackwood RA, Bloom KR, Williams CM. Aortic stenosis in children. Circulation 1978; 57: 263-8.

${ }^{38}$ Weyman AE, Feigenbaum H, Hurwitz RA, Girod DA, Dillon JC. Cross-sectional echocardiographic assessment of the severity of aortic stenosis in children. Circulation 1977; 55: 773-8.

${ }^{39}$ Lambert EC, Menon VA, Wagner HR, Vlad P. Sudden unexpected death from cardiovascular disease in children. Am $₹$ Cardiol 1974; 34: 89-96.

${ }^{40}$ Reynolds JI, Nadas AS, Rudolph AM, Gross RD. Critical congenital aortic stenosis with minimual electrocardiographic changes. $N$ Engl $f$ Med 1960; 262: 276-82.

${ }^{41}$ Landtman B, Louhimo I, Wallgrew EI. Congenital aortic stenosis in children. Follow-up of 103 conservatively treated cases. Acta Chir Scand 1966; Suppl 356B: 26-34.

${ }^{42}$ Reid JM, Coleman EN, Stevenson JG. Management of congenital aortic stenosis. Arch Dis Child 1970; 45: 201-5.

${ }^{43}$ Spencer FC, Neill CA, Bahnson HT. The treatment of congenital aortic stenosis with valvotomy during cardiopulmonary bypass. Surgery 1958; 44: 109-24.

${ }^{44}$ Lees MH, Hauck AJ, Starkey GWB, Nadas AS, Gross RE. Congenital aortic stenosis, operative indications and surgical results. $B r$ Heart $\mathcal{F} 1962 ; 24$ : 31-8.

${ }^{45}$ Thomson NB Jr, Fisher FC. Long-term postoperative follow-up in surgery for congenital aortic valvular stenosis. Circulation 1965; 32: 732-9.

${ }^{46}$ Fisher RD, Mason DT, Morrow AG. Results of operative treatment in congenital aortic stenosis. Preand post-operative hemodynamic evaluations. $\mathcal{F}$ Thorac Cardiovasc Surg 1970; 59: 218-24.

${ }^{47}$ Shackleton J, Edwards FR, Bickford BJ, Jones RS. Long-term follow-up of congenital aortic stenosis after 
surgery. Br Heart $\mathcal{f}$ 1972; 34: 47-51.

${ }^{48} \mathrm{Jack}$ WD II, Kelly DT. Long-term follow-up of valvulotomy for congenital aortic stenosis. $A m \mathcal{F}$ Cardiol 1976; 38: 231-4.

${ }^{40}$ Gersony WM, Hayes CJ. Bacterial endocarditis in patients with pulmonary stenosis, aortic stenosis or ventricular septal defect. Circulation 1977; 55 and 56, suppl I: 84-7.

Requests for reprints to Dr J M Neutze, Cardiology Department, Green Lane Hospital, Green Lane West, Auckland 3, New Zealand. 